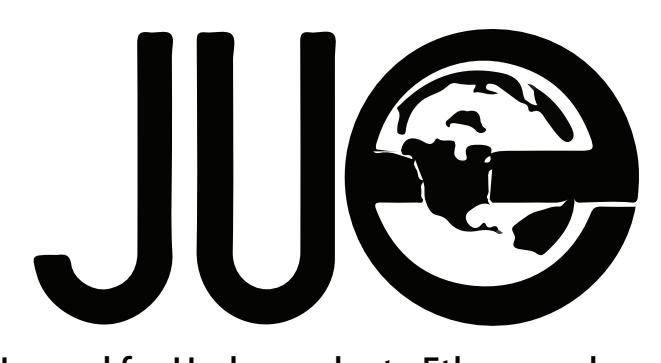

The Journal for Undergraduate Ethnography

Volume 6| Issue 1

ISSN 2369-8721

\title{
Economies Of Waste: Rethinking Waste Along the Korle Lagoon
}

\section{Debbie Onuoha}

Harvard University, debbieonuoha@gmail.com

\section{ABSTRACT}

This article focuses on practices of recycling that have emerged along the Korle Lagoon in Accra, Ghana in an attempt to rethink the role of trash in the city. Many have predicted that the city's garbage nightmare will be its doom. Much of Accra's trash ends up along the Korle Lagoon, near Old Fadama and thus the slum is blamed for the pollution of its waters. In what follows, I first examine instances of these allegations from the present day, and then juxtapose them with archival evidence. Using the historical record, I show that the history of trash in the Korle extends earlier than the establishment of the settlement and that moreover, the pollution of the lagoon begins upstream even before it passes by the slum. Old Fadama, I argue, is not-as has been believed-the principal polluter of the Korle. Instead, using ethnographic evidence from fieldwork conducted along the lagoon, and drawing inspiration from the concepts of the biological city developed by Wolman, Girardet and Gandy, the article suggests that rather than holding Accra back, the economies of waste facilitated by the lagoon and the slum have actually rechanneled some of this refuse, thereby contributing to certain forms of city-making. 


\section{Introduction}

At the start of the new millennium, the Ghana Institute of Architects, in collaboration with the Goethe Institute, convened a conference on the future of Accra as a global 21st century city. Proceedings from the conference, which were subsequently published in a fourteen-part compilation entitled: Visions of the City: Accra in the 21st Century, included Nana Araba Apt's "Accra in the 21st Century: Visions from the Crystal Ball of a Sociologist.” In her chapter, Apt forecasts a daunting future for Accra: The plastic debris that now engulfs our city was not there 20 years ago. It will continue to choke the city like unwanted vermin in the next 20 years as we meet our promised vision for "plenty in 2020 (Apt 2002, 46)."

Within her prediction are two major claims about the city's past and future respectively. In the first place, Apt views the presence of garbage within Accra as a modern manifestation, which "was not there 20 years ago." Second, she depicts the city's disposal problem as an intractable one that will "continue to choke the city" thus threatening its survival. I take these two claims as a point of departure to explore waste management in Accra.

In this article, I make one main intervention. I argue for an examination of Accra's trash that does not simply identify it as a difficulty that threatens to overrun the city, but rather takes into consideration some of the ways in which the city's garbage has shaped its growth. Whereas much early literature on waste focused on disposal as a technical problem, more recent approaches have advocated for an examination of its social dimensions: which new structures have emerged as a response to the build-up of rubbish in many of the world's cities, and how do these shape the urban landscape? Notable among such studies is Mikael Drackner's "What is waste? To whom? (2005)." Drawing empirical material from Tacna, Peru. Drackner explores five main ways in which waste may be perceived: "as a risk, as a social contagion, as belonging in dirty places, as an asset and as someone else's problem," to show that at any given time and place, the same thingi.e. garbage-may be experienced and conceived of differently by people within various contexts. Taking Drackner's example, this paper also attempts to locate alternative perspectives on waste and its use, outside of the dominant narrative. Using the Korle Lagoon in Accra, Ghana-long a receptacle for waste within the nation's capital-I examine the effects of garbage on the city, not merely in apocalyptic terms as many have tended to do, but instead by paying particular attention to how the recycling economies that have emerged around the Korle serve to produce new social and economic configurations within the growing city. To develop this argument, I begin by describing my research process and then review scholarship on waste and urban metabolism within the field.

\section{Methodology \& Positionality}

This article uses material collected as part of a larger research project on discourses of pollution around the Korle Lagoon. Information was gathered during two fieldwork trips: Dec 2013-Jan 2014 and May-August 2014, as well as almost two years of related coursework. During this time, I spent several weeks by the lagoon interviewing those who lived there, and walked along the streets of different communities in Accra to get a sense of what residents had heard and thought about the Korle. At present, public opinion strongly accuses the slum of causing the lagoon to become polluted and "dead". In order to examine the present narrative, it was necessary to compare it to the historical record and see whether the genealogy of pollution that is often presented by city officials and residents would actually hold up. Therefore, I also conducted searches of the city's libraries and national archives for texts concerning the Korle. The kinds of sources and methods used in this project, stem from my training in history, literature and anthropology, and are similar to those often used in historical anthropology. My approach, for instance, combines official government letters and maps gathered from the national archives with close readings of a video and a comic, or oral 
histories with traditional authorities and ethnographic observations-both written and filmed-in an attempt to arrive at a multifaceted conception of how both the lagoon and pollution are perceived and responded to within the city.

Many of these observations were, to a great extent, influenced by my position within various communities along the lagoon: I was strange but not too strange, familiar but not uncomfortably so. To residents jaded by international visitors and attention, my identity as a Ghanaian student who could interact with others in Twi-the most widely spoken local language-or Pidgin English meant that fellow Ghanaians were more ready to engage with me. And among other West African migrant groups my fluency in French and my Nigerian heritage had much the same effect. On the other hand, I was also sufficiently strange. In a community that is heavily looked down upon by the rest of Accra-a reality conveyed by the nickname "Sodom and Gomorrah" given to the slum-being a student from "abrokyire" (i.e. "America", or more accurately an American university) gave me some distance from the rest of Accra, enough perhaps, that I could ask seemingly obvious questions (like "does the Korle Lagoon matter?") and still be answered.

Another factor that shaped my interactions along the lagoon was the video-recording equipment in my possession. Having spent two years engaging with sensory ethnography, my research process culminated in Fadama (2014) a 25-minute nonfiction film about work at the e-waste dump, as well as longer written piece on discourses of pollution. The possession of a camera and the process of filming imply a subsequent act of viewing and therefore an audience. For this reason, though I explained that my film would not contain dialogue or interviews, many people were keen to address my lens and correct misconceptions about their community. Surprisingly, even those who had voiced a strong distrust of cameras appeared eager to talk to me about this, in order to explain how both local journalists and international freelancers had preciously taken advantage of them. Here too, being at the intersection of both local and foreign-a Ghanaian-Nigerian schooled in America-meant that people seemed more willing to speak with me.

Lastly, in some cases I suspect there may have otherwise been pushback against a stranger asking questions about the lagoon, or wanting to film people at work-especially at the controversial e-waste site-but the fact that I was a student and a young woman mostly on my own seemed also to make others want to help me. Once my interlocutors or I explained that I was working on a school project I got a more favourable reception, almost as if everyone felt responsible for contributing to my academic success. Moreover, in a slum mostly led by older men, being a young woman rendered me harmless in the eyes of many that I met, and made them more permissive of my witnessing and even documenting some otherwise heavily guarded activities.

In turn, these encounters informed my investigation. Often nature is presented as "the last remaining place where civilization, that all too human disease, has not fully infected the earth" (Cronon 1996, 69-90), and urbanism as a destructive process that encroaches upon it. Such has been the case in Accra: the media reiterates accounts of a recently devastated lagoon, and then of the settlement that caused it, as well as the detrimental effects it has on the city. Yet the information I received did not fit this: I found that the Korle's pollution went well beyond what was remembered, that a host of other factors beyond Old Fadama were responsible for its contamination, and that moreover the slum could be said to have had some constructive effects on Accra. This paper reflects the challenge that such findings pose to the mainstream view-the simplistic depiction of the lagoon as a victim and the slum as its aggressor. 


\section{Beyond the Bacteriological City}

In a seminal work within the study of urban metabolism, American intellectual and sanitation engineer Abel Wolman defines "The Metabolism of Cities" as the sequence of processes required to provide a given city with all its resource consumption and waste disposal needs:

The metabolic requirements of a city can be defined as all the materials and commodities needed to sustain the city's inhabitants at home, at work and at play...The metabolic cycle is not completed until wastes and residues of daily life have been removed and disposed of with a minimum of nuisance and hazard.

(Wolman 1965, 179)

Drawing examples from American cities such as New York and Los Angeles, Wolman focuses on three major areas in which metabolic dysfunction often arises, as cities expand and are less able to appropriately discard their waste. These three are "adequate water supply", "disposal of sewage" and "air pollution". Within the article, focusing mostly on the use of water, he then models a hypothetical American city whose input-materials greatly exceed its output-waste. Using this model, Wolman attempts to demonstrate the detrimental effects of the compilation of garbage on the health of urban centers.

Building upon Wolman's concepts, cultural ecologist Herbert Girardet in "Regenerative Cities"-his report for the World Future Council-takes the idea of an urban input/output balance a step further. He prescribes a shift in policy from striving for the "metabolic city" and proposes instead that cities work towards what he terms the "regenerative city". In explaining this, Girardet first differentiates between the two forms of metabolism inherent in nature (i.e. circularity) and cities (i.e. linearity) respectively:
Nature essentially has a circular zero-waste metabolism: every output by an organism is also an input which replenishes and sustains the whole living environment. In contrast, the metabolism of many modern cities is essentially linear, with resources flowing through the urban systems without much concern about their origin, and about the destination of wastes. (Girardet 2010, n.p.)

Unlike the natural environment, where an output in one context is simultaneously an input within a different scenario, Girardet contends that within most modern cities, inputs and outputs are largely unrelated, contributing to the pileups of waste material the world over. As a solution, he prescribes the establishment of "Ecopolis"; rather than merely reducing waste produced, such "regenerative cities" will introduce forms of circular metabolism into urban centers. Whereas the "metabolic" city sought simply to dispose of waste, this its "regenerative" counterpart would aim higher and "positively enhance rather than undermine the ecosystem," by finding ways to reincorporate waste into systems of production as new inputs.

Though recognizing the usefulness of each of these biological metaphors-which he himself terms "the biological city"-as a useful entry point for imagining the city, urban geographer Matthew Gandy (2010) contends that reducing the urban landscape to inputs, outputs and flows in this way inhibits an examination of all the complexities inherent in today's global cities. Instead of just conceptualizing the city as an efficient homeostatic machine, Gandy makes two points. . The first is that everything works more messily in the increasingly globalized present; "metabolism" is not merely determined by policymakers, as Wolman and Girardet seem to suggest. Rather, in some cases, particularly in the Third World, city flows are conducted from the bottom up. Secondly, he argues that hydrological infrastructures-and other metabolic systems that facilitate urban flows-are not merely functionalist but also dialectical: they do not just do things for the city but also to it, making the relationship between nature and cities mutually constitutive. In line with this claim, the article centers primarily on the movement of water, emphasizing: "the symbolic 
role of water infrastructure in the modern city and the emergence of new forms of social and cultural hybridity" (Gandy 2010, 364).

In what follows, I apply Gandy's approach to an investigation of waste disposal (or the lack thereof) along a different hydrological system: the Korle Lagoon in Accra, Ghana. Using the concept of metabolism as starting point, I examine how Accra's waste products are managed and reused along the lagoon. In addition, I look at the social and economic changes that have been facilitated in the city through the intervention of this body of water on the urban landscape.

\section{"Garbage Nightmare"}

On 23rd May 2014, the Black Narrator-an anonymous Ghanaian political cartoonist, affiliated with national newspaper The Daily Graphic-posted a cartoon entitled "Garbage Nightmare" onto his/her Facebook page. In it, a terrified figure, bearing a striking resemblance to the Mayor of Accra, Alfred Nii Oko Vanderpuije, attempts to escape being captured by the colossal trash-monster behind him. The beast, with an overflowing trashcan for a head, and similar litter comprising a body-such as empty bottles on his back, a used syringe in his right thigh, a spoon on his belly, chicken bones in his side, and an old television set on his back-leans forward in pursuit: arms outstretched, with fingers poised to grab a fleeing Mr. Vanderpuije.

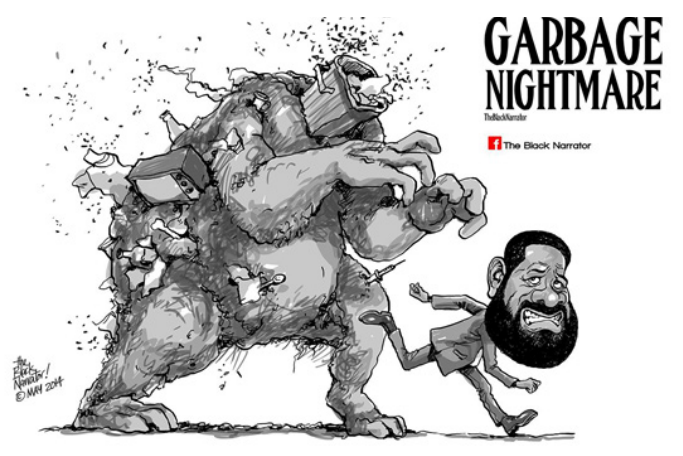

Figure 1 The "Garbage Nightmare", Cartoon by the Black Narrator, 2013 (reproduced with permission)
To those familiar with Accra, this cartoon launches a poignant critique of the city's decades-long struggle to cope with waste both locally and internationally produced.

At present, 2,500 tonnes of waste are generated daily throughout the city and the Accra Metropolitan Assembly (AMA) - the planning and management authority for the nation's capital-is only able to deal with an estimated $60 \%$ of it all (Boadi and Kuitunen 2003). In 2013, for instance, the situation came to a head with the closure of the Oblogo landfill site, a popular metropolitan dumping location. For several days the lack of a replacement disposal site meant that garbage collection stalled, and waste piled up in locations across Accra. With the announcement by Samuel Kpodo, the AMA’s deputy director for waste management that "we still lack a final disposal or dump site for the Accra Metropolis" (The Weekend Globe 2003), anxieties began to escalate about the threats to hygiene-such as an outbreak of cholera-that such piles of rubbish could pose to residents.

Unfortunately, locally produced trash-though itself a major problem-is not the only kind that fills the city. In recent years, Accra has emerged as a digital dumping ground where millions of electronic waste products-symbolized by the television on the back of the trash monster in The Black Narrator's cartoon above-from the Western world are annually sent off. Initially begun under the guise of providing affordable second-hand devices for use in less developed countries, the movement of technology into Ghana now takes the form of derelict equipment. Foreign companies, unwilling to bear the costs for the proper recycling of their old electronics, instead sell them to dealers. These middlemen then illegally smuggle such items into the country to be cast away at sites such as Agbogbloshie near the Korle Lagoon in Accra. Here, these electronics are broken down and burnt by groups of otherwise unemployed young men. Then, copper wiring, and other valuable components are gathered and sold to larger foreign recycling companies in order to earn an income. As a 
result of these electronic waste dumps, and recycling activities, the Agbogbloshie area is now ranked alongside Ukraine's Chernobyl among the top ten most polluted places on the planet in a report produced by two pollution-based non-profit organizations, the Blacksmith Institute and Green Cross Switzerland (2013).

If the Mayor of the cartoon represents Accra, then it may well be said that the monster which plagues the city is its own creation: the "Garbage Nightmare" that haunts Accra is one that the city itself has bred and fed to such horrendous proportions, through failing to adequately dispose of its own domestic waste, and also in allowing refuse from foreign countries to pile upon its shores. It is at the center of the city, along the banks of the Korle Lagoon, that most of this waste washes up.

\section{Korle Lagoon-Odaw River}

With a catchment area of about $400 \mathrm{~km} 2$, the Korle Lagoon is the city's largest drainage system (Boadi and Kuitunen 2002). From the hills of Abokobi and Adjankote in the north of the city, water flows downwards through the Odaw River and its tributaries and into the Korle Lagoon near Accra Central, emptying out into the Atlantic Ocean at the Gulf of Guinea. The Odaw River is the largest tributary of the Korle. There is no exact point at which river becomes lagoon, only approximation. For this reason the two names are sometimes used interchangeably in news reports. For much of the 21st century, the dream has been to establish a tourist resort along this lagoon. This vision was reiterated in 2013, when the AMA promised, as part of its city upgrade scheme, to "transform the filth-laden Korle Lagoon in Accra into a modern pleasure and transport complex comparable to those in Paris" (Radio XYZ 2013). If successful, this would radically alter the Korle from its heavily polluted present state.
Sources of pollution to the Korle are many. Factories in the industrial area as well as the nearby Korle Bu Teaching Hospital's mortuary discharge effluent into the lagoon. Faecal matter, dumped into the sea by the city at the ironically-named "Lavender Hill", may backwash into the lagoon, and residents of nearby communities often throw domestic waste into the Korle Lagoon and its tributaries. Decomposition of these toxins depletes oxygen resources and as a result, plant and animal life cannot be sustained. Siltation also causes huge problems. Sediments wash in from the banks, clog the bed of the lagoon, block drainage into the sea, and cause the water to stagnate. Still waters then pose a danger to human life and property: they breed mosquitos, making malaria more likely; host pathogens which cause cholera, typhoid and so on; and create risks of flooding during the rainy season when the lagoon overflows into neighboring communities, damaging homes and other structures.

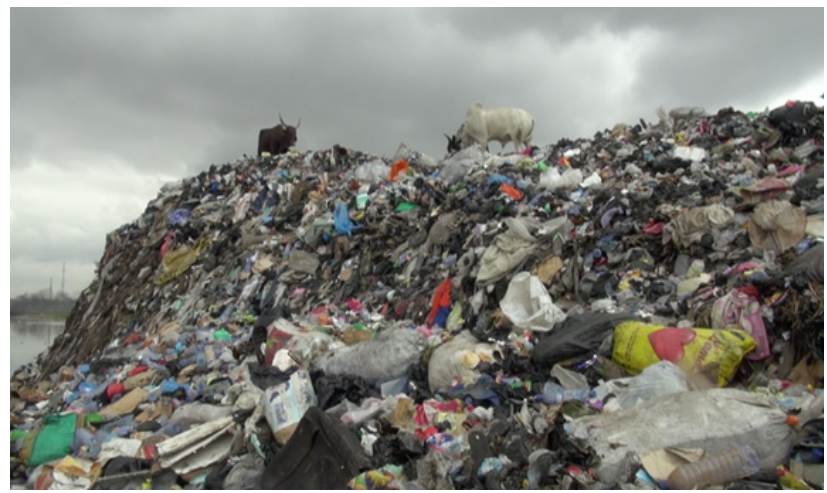

Figure 2 "Trash Mountain," Still from film Fadama by Author (Onuoha 2014) 
Though many do remember moments in time when the Korle provided ample tilapia and crabs for local fishermen, a swimming spot for young boys, and a hub of canoe transport for traders, present uses of the lagoon are a far cry from this its idyllic past. Nowadays the Korle Lagoon exists as one of the planet's most polluted bodies of water. Direct comparisons are thus often drawn between the lagoon's current state as "dead" and memories of it as a thriving source of fish. The following excerpt from The Daily Graphic illustrates this:

The Odaw River has not only become a dumping ground for solid waste but also a receptacle for excreta, as some people squat along its banks to freely attend to the call of nature, even in broad daylight. As a result of this extensive pollution, the Odaw River is virtually dead. There is hardly aquatic life in the river, especially at places where pollution is very severe. Many years ago, people used to fish in this river. (The Daily Graphic 2012)

Often, "many years ago" is taken to signify an era within the same lifetime, and in particular just up until the 1990s, when the community of Old Fadama was established along the Korle's banks.

Popularly referred to as "Sodom and Gomorrah", the Old Fadama slum is home to about 100,000 of the city's poorest residents, mostly from the country's Muslim north. Lacking access to garbage collection and other basic services provided to communities elsewhere in the city, most residents dispose of household waste and sewerage by dumping into the nearby water. The municipal authority and local media consequently tout these activities as the greatest dangers to a restored lagoon, contending that it was the establishment of the slum and its poor sanitation habits that have made the water so unclean, and that their removal will therefore allow for the development of the lagoon and its environs.

\section{"Because of this Sodom and Gomorrah"}

"Because of this Sodom and Gomorrah enti na eye saa [that it is like that]!" This was the opinion voiced by the Korle Wulomo-Chief Priest of Naa Korle, the Korle Lagoon's eponymous resident deity-when during an interview, I asked him about the lagoon. To restore the Korle, he continued, this cause of its pollution would have to be eliminated: "It is my wish and my desire we should dredge the lagoon and we should remove the Sodom and Gomorrah people from there, then the lagoon will go back to how it used to be in the past." This is an allegation that is often heard in Accra about the role of Old Fadama and its inhabitants in polluting the Korle Lagoon. Like the Wulomo, many blame the dumping of the slum's domestic waste into the lagoon (an action admitted by residents) for its polluted and clogged state (Onuoha 2015). Some even go a step further, accusing the slum of spoiling the water by dumping human corpses into it: Akua, a 20-year city resident recalled rumours that "some of them" conduct abortions and dump the foetuses into the lagoon, and Nii Tackie, an Accra native, was adamant that "the Northerners kill people and put them inside," thus bringing both pollution and crime to the banks of the lagoon.

Considering the lore surrounding the Korle Lagoon and Naa Korle, these accusation highlights the perception of the Old Fadama settlers as a source of corruption to the city. The deity Naa Korle, it is widely known, despises filth, especially that of dead bodies, and several stories abound in which she exacts her revenge upon those who have dared to approach her waters with a human corpse in their possession: "During funerals," I was warned, "if you cross the bridge, coffin will go!" According to one very popular story, a group of Ashantis (an ethno-linguistic group from the interior) on their way to a funeral drove their hearse across the Guggisberg Bridge. This bridge passes over the Korle Lagoon, right beside the clump of mangroves near its center, where Naa Korle is believed to dwell. The trunk of their car was 
immediately yanked out of it. In some iterations of the tale, the corpse was cast up into the sky, and in others, it was flung down into the depths of the Korle. Worst of all, when told by the Wulomo, a further curse accompanied all the relatives of those responsible: "If you carry a dead body over that bridge, your entire lineage will be destroyed, no one will survive." Within this context, stories about the dumping of foetuses and the murdered into the lagoon are accusations of the slum as polluting the Korle on a spiritual as well as a physical plane, and thereby doubly deserving of removal.

These accusations are perhaps no louder voiced than in print and audio-visual media. This can be seen in a three-minute documentary on the Korle Lagoon, created by YouTube user selasekove that locates the slum as the exact spatiotemporal point at which the lagoon's waters were spoilt. Aptly titled: "Sodom and Gomorrah: Between a City and its Dream" (2011), the piece introduces the "dream," i.e. the AMA's future plans for converting the lagoon into a tourist resort of sorts. Right from the start, the video devotes much of the narration and images to situating "Sodom and Gomorrah" as a major obstacle to the dream's realization, as it is lodged firmly between Accra and this vision for a beautified lagoon. The clip opens with scenes of fishing boats on the open sea, houses along a waterside resort, and people strolling and riding horses along a beach waterfront. These images of aquatic recreation are abruptly cut short by shots of trash piles, men burning plastic amidst dense smoke, and shacks packed tightly together. The juxtaposition of images of waterside leisure (symbolic of the dream) with garbage (representing the slum community in which it was shot), that is present on the visual track, is also mirrored in the audio, as the narrator tells us:

The Korle Lagoon... has been identified by city authorities as one natural resource, which can serve as a source of tourist attraction when given a facelift...
But somewhere not too far from this lagoon, lies an obstacle to this dream...Sodom and Gomorrah. This slum is the point where the pristine waters of the lagoon have become murky, silted and lifeless.

From there, the video goes on to describe the establishment of the slum, tracing when the "the pristine waters of the lagoon [became] murky, silted, and lifeless." Together, the progression of the sound and video channels mimic the supposed role of "Sodom and Gomorrah": like the jolting cuts in the editing from beach to trash pile, the slum by its existence-or so we are led to believedisrupts the reality of what was, and perhaps could again be, a clean and picturesque lagoon at the heart of the city.

Though many blame the slum for polluting the water, the reality is that even before the slum appeared, the Korle Lagoon had long served as Accra's waste receptacle.

\section{Korle in the 20th Century}

Some of the first gutters and pipes to be laid in Accra in the 20th century emptied into the Korle's mouth where the lagoon's flow could then channel them into the sea. Moreover, night soil workers from the period were often instructed to dump their loads into the Korle (Tahal Water Planning Ltd. 1965). Unfortunately, as the city grew-and the waste flowing into the lagoon with it-city authorities consistently failed to upgrade the pipe and gutter systems to accommodate the swelling volumes of foul water. As documents in the national public archives show, a proposal to renovate the lagoon's sea outfall gate was rejected in 1946 (PRAAD 1), and as a result, by 1956, wastewater began to overflow well beyond the limits of the collecting drains that had been put in place decades earlier (PRAAD 2). Yet again, proposals for the installation of adequate sewer systems were drafted then discarded, since neither the colonial national government nor the Accra Town Council (predecessor to the AMA) were willing to provide funding out of their organizational budgets for 
construction on the lagoon (PRAAD 3). Instead of continuing into the sea, sewerage from the pipes and garbage from the gutters began to collect in the lagoon, causing pollution and concerns about hygiene.

Yet another incident would add to pollution in the Korle, as documented by Jonathan Roberts (2010) and K. David Patterson (1979). At the height of the Second World War in 1942, when supply routes from the Mediterranean to North Africa were disrupted and diverted to West Africa, Accra became a major stopover spot for the Allied forces. However this alternative almost immediately presented problems of its own. The 37th General Hospital of the British Empire, which had been set up to treat soldiers' war injuries, increasingly became inundated with malaria cases such that during the rainy season that same year, $62 \%$ of British soldiers in one camp were admitted with the disease. Despite the fact that soldiers had been housed on a ridge, far away from the city center, outbreaks of malaria in the military camps were blamed on the disease-ridden bodies of locals along the banks of the Korle, itself "swarming with Anopheles larvae.” Along with the Germans, malaria-associated with the lagoon-became another adversary standing in the way of an allied victory, and posters were created urging soldiers in the dual fight against Hitler as well as the threat of infection. When a Japanese invasion of Java in Indonesia cut off the Allies' principal source of quinine, a popular antimalarial drug, a new solution had to be sought. Unsurprisingly, these efforts targeted the heart of Accra: the Korle. The idea was to eliminate the mosquito breeding grounds rather than treating the disease in humans. But re-engineering the lagoon, as had been done in other colonies, proved too expensive. Thus, British and American troops launched their own incursion into the lagoon via the Inter-Allied Malaria Control Group (IAMCG). In 1945, British and American forces poured oil and sprayed large quantities of insecticide and larvicide into the lagoon in attempts to eradicate the mosquitoes. In particular, pyrethrum and dichlorodiphenyltrichloroethane (DDT) were the chemicals that fogged up the Korle's waters.

Therefore by the 1960s-long before most people would trace the contamination of the Korle-the lagoon was already notorious for its "obnoxious smells" and "offensive condition" (PRAAD 4), according to a speech by Mr EK Benson, the then Minister for Communication and Works, during the commissioning of the Guggisberg Bridge in 1963.

Decades later, by the time Nat Nunoo-Amarteifio began his four-year tenure as Accra City Mayor in 1994 not much had changed. Indeed by the 1990s, before the establishment of Old Fadama as a temporary settlement, trash was already ubiquitous in the lagoon's environs, as he described in an interview:

At that time the banks of the Odaw River leading to the lagoon was an empty lot that was used as a dumpsite for the city's garbage. A lot of garbage was ending up in the Odaw River and helping to pollute it. It was also flowing downstream into the Korle Lagoon and blocking the outlet of the Lagoon into the sea. This was resulting in the yearly flooding of the city.

Subsequently, in one of many reiterations of the Korle Lagoon Ecological Restoration Project (KLERP) launched to mitigate pollution and reduce flooding along the Korle, money was secured from the Kuwaiti Fund to dredge the lagoon and from the British government to build a solid waste management system. Though the growth of the slum, its adjoining market and eventually the e-waste dump may have increased the rate at which waste matter was introduced into the Korle, the failure of these two projects meant that the original cause of the Korle's pollution-improper waste disposal throughout the city of Accra-persisted too. 
In the past few years, the Environmental Protection Agency (EPA) in Ghana has undertaken several biological and physio-chemical studies of the lagoon. For instance in 2013, a team from the EPA launched a "reconnaissance survey and monitoring" of the Korle Lagoon and the Odaw River. Though many believe that it is the activities of Old Fadama that have caused a decline in the water quality, experts say that were the slum not to exist, the Korle's prospects would be just as dim. As Dr. Sam Adu-Kumi, a scientist in Accra's EPA, expressed when I interviewed him:

The pollution is all over. Even right from the point source you can see that there is refuse dumps [sic] close to the place and these things are thrown into the river even from the source, so its true that it's polluted right from the source.

Although the community's dumping undeniably contributes to the pollution of the Korle, studies show that there is a very minor difference in levels of pollution of the Korle between its mouth near the sea, and its source far to the north. Before arriving at Old Fadama, the Korle is polluted by the region's industries, $30 \%$ of which are located in its catchment area and dispose of their untreated effluent into its waters. The rest dump waste into network drains which later feed into the lagoon too (Acquah 1998). In other words, much of the solid waste and effluent present in the lagoon is introduced into it long before its waters pass by the Old Fadama slum. According to the report the "indiscriminate dumping of garbage, open defecation, domestic discharges, mechanic shops, car washing bays", and unlawful construction in and around the riverbed are some of the many activities to which the EPA attributes the heavy pollution of the Odaw and by extension the Korle too. Even before it enters the Greater Accra Region (within which Accra is located), human activity from an hour away in the Eastern Region-including a waterside dump located right in front of the house of a parliamentary minister!- - has

\section{Sitting on a Waste Timebomb?}

As a 2013 article "Accra is Sitting on a Waste Timebomb" in The Weekend Globe expressed, several people predicted that the city would become "choked" by its waste in short order. And yet several of these predictions greatly underestimated the beginning of the contamination in the center of the city, which then flows out along the Korle Lagoon. To some extent, this change in the perception of the lagoon's trash past raises questions about the ways in which we consider its future. Having pushed the sources of pollution on the Korle back by several decades, one may wonder, what becomes of the end date: how has the city not already been overrun by filth as was projected?

A major shortcoming of predictions such as those advanced by Apt, Wolman and Girardet is that they view waste as stagnant outside of official government interventions. Without some sort of drastic change from authorities, they assume that trash will simply continue to accumulate to the ruin of the city. This is not always the case. Reasons for this perhaps lie, as Gandy suggests, in attending not only to the presence or absence of metabolic trash pathways within the city, but also to their on-theground communal effects. When there is insufficient or no official action, individual actors take matters into their own hands, resulting in many grassroots changes in the urban fabric.

In other parts of the world, similar accounts have emerged concerning how the management of trash may be turned into a profitable industry for the more marginalized sections of society. After the Argentinian financial crisis of 2001-2002, Risa Whitson (2011) and Kate Parizeau (2015) each document the situation of "cartoneros", groups within Buenos Aires who make a living from collecting and processing recyclables from the homes and streets within the city. A.S. Moates similarly (2010) presents an insight into the lives of "classificadores" in Uruguay following its own economic strains in 2002. These "classificadores", in addition to recycling waste, are also able to raise hogs for sale on 
the organic refuse they come upon in their line of work, thereby generating further sources of income from their engagement with waste. In each case, informal recycling practices provide opportunities for members of various groups to make a living and earn money by working with an otherwise overlooked but ubiquitous resource: waste. Where opportunities are scarce, informal recycling becomes a way to enter into the economy as income-earning citizens.

Similarly, I now focus on economies of waste that have emerged along the Agbogbloshie Scrap Yard and along the slum community of Old Fadama. As was demonstrated earlier, contrary to popular belief, the Old Fadama slum cannot possibly bear sole responsibility for the build-up of waste matter in the Korle Lagoon-something that was well underway at least forty years before the slum was ever established. Indeed instead of being the primary cause of pollution to the lagoon, the slum and its residents have become, I will argue, one of the key conduits by which garbage circulates-rather than stagnates-along the Korle.

\section{Agbogbloshie E-Waste Dump}

Amidst the mounds of scrap surrounding the Korle Lagoon, elaborate routes of recycling have emerged around the many different kinds of waste materials available. The vignettes described below are taken from scenes in my documentary film Fadama (Onuoha 2014), which is an exploration of "Sodom and Gomorrah" and the types of work that take place there.

A group of high-school friends collect and dismantle televisions-breaking up the plastic shells, shattering the glass screens and salvaging only their wire skeletons, which they pile upon a wheelbarrow and haul off to market. Not far off, young men hammer away at everything from old engines to electric fans and computer motherboards. Behind billows of black smoke nearby, another group of twenty young to middle-aged men stoke the blue-green flames that melt off plastic wire casings, exposing the bright copper strands, which they too lug onto a wheelbarrow and off to a trader. Further along, six burn up leftover plastic casings-such as old computer units-out of which these wires were ripped. A few metres down, two trios zig-zag in and out of the trash heap, each with a collecting bag in one hand and a searching stick, for pushing away unwanted rubbish, in another. These men (sometimes referred to as "scavengers" by journalists) rifle through the mound beneath them, each combing for his own collector's item-for one, glass bottles, for another, aluminium soda cans, and for another still, plastic water sachets. These scraps, they tell me, are eventually sold in bulk to a Chinese recycling company. But first, they would be taken to one of the many middlemen who keep storehouses within the market and the scrapyard.

On many levels, what one finds at Old Fadama is not entirely unlike Girardet's regenerative city, where those things that are cast off as outputs are quickly channelled into new productive circuits. With no dustbins or garbage disposal facilities provided within the slum (and some parts of the rest of the city), many view dumping into or near the water as a lesser evil than incineration (Onuoha, 2015). Instead of burning-which would release toxic gases into the air-some of the trash is put to other uses. At the same time that shipments of old metal parts are offloaded, groups of workers retrieve scraps, sorting then selling them for money. In the very space where residents empty out bucket-loads of household trash, cattle and birds feed on what grass and bits of food are to be found. Thus, along the lagoon, one notices the concurrent drop-off and pick-up of these different kinds of waste.

Understandably, the recirculation of waste does not presently occur at a pace that allows it to completely reverse the pile up of mounds and mounds of garbage and sewerage along the lagoon. Regardless, it has resulted in significant changes of social formations within this section of the city. In particular, it serves as a means of integration for new migrants, it provides a source of subsistence for a considerable segment of society, and lastly it 
contributes to the making of social and economic groupings even within the slum.

\section{Trash and City-Making}

In addition to recycling, these activities have helped to shape the experience of many new migrants into the city. The Korle serves as a preliminary springboard for new migrants, until they find their feet and can afford better alternatives, as described by Maemuna, a middle-aged resident.

In all of Accra, this is the only place that you can come to. Nobody wants to come here, but when you come from the North there is nowhere else. Unless you come here, then you hustle for a while, that's when you can make a little bit of money, enough to find somewhere else to go.

For the newly-arrived the lagoon and the trash that surrounds it provides an opportunity to become economic citizens, that is, to find an income, housing and employment within the big city. In this regard, this space has become a site of social cohesion-a point that was very often emphasized in conversations with residents during my time there as justification for why they should be allowed to remain. This is not just limited to new migrants-informal economies like those that have emerged along the Korle have provided a means of living for many people in Accra.

As the nickname "Sodom and Gomorrah" indicates, the slum community that has developed along the Korle is not particularly liked by majority of the residents of Accra. Like its Biblical counterpart, many believe first that the slum's destruction is inevitable but more importantly that it has become a center of social degeneration that threatens to infect the city (Onuoha, 2014). To the contrary, many community members described their presence on the lagoon as facilitating, not threatening, the city's peace: according to them, without the opportunities that the slum provided they would "be forced to turn to stealing" to make a living. Having grown so rapidly in recent years, the city, through authorities such as the AMA, is unable to adequately deal not only with garbage and sewerage but also with the provision of other amenities such as housing and employment. Since half of Ghana's urban population lives in slums (Kuria, 2009) and works in the informal economy (GSS 2008), the opportunity to live in the slum and to work with trash therefore becomes an informal alternative in the absence of government-made jobs and accommodation. It is thus conceived of as something constructive that contributes to the making of the city, rather than as something destructive that threatens to unravel it (as the cartoon, and the prediction by Apt suggest), by those who live there.

Lastly, the Korle has also been influential in the making of socioeconomic categories within the slum. Trash collecting along the lagoon is fairly differentiated. Interestingly, each of these specializations comprises groups of men with the same or similar regional origins. Somewhere near the top-after the scrapyard Chairman and his committee-these middlemen consist largely of Nigerians and others from the north of Ghana. In the middle, more Northerners (who make up the majority of the slum), perform most of the breaking and burning. And at the very end of the hierarchy, many of the "scavengers" I met come from other West African countries such as Benin and Togo, and a small minority of them from other very rural parts of Ghana. Whilst each of the scrap metal workers has a relatively defined space within which he works (and to which old electronics and engines are dropped off), these trash-pickers are constantly moving: looking through the growing trash heap for recyclables. According to one of them, the barrier that prevented them from advancing into scrap work 
was a linguistic one: "C'est les gens qui ne parlent pas l'anglais qui font ce travail. [i.e. It is those who do not speak English who do this work]."

Though there may well be other reasons for this, overall it is clear that at the Korle Lagoon there is more to be witnessed and explored than the build-up of waste along the banks. For instance it is useful to examine the economies that have emerged around the handling of waste, that is, how the trash moves, and how this has in turn impacted social cohesion within the city.

\section{Conclusion}

From both local and international sources, garbage and sewerage is being introduced to Accra at levels that exceed the ability of the Metropolitan Assembly to adequately dispose of them. Urban theorists such as Wolman and Girardet have discussed the danger that cities face when their outputs exceed their inputs in this way, and cities are unable to manage their trash. In the case of Accra, much of this waste ends up being dumped in and around the Korle Lagoon at the center of the city. The buildup of refuse here has caused anxieties about the future of the city, as is evidenced by the cartoon "the Garbage Nightmare" and Apt's "Accra in the 21st Century", which suggest that the trash problem might overrun the city before long.

This paper contributes to literature that treats the concept of waste as subjective: such an approach maintains that the very things that some view as a source of risk and/or contagion, are simultaneously perceived as opportunity by others. For Drackner, these varying notions of waste are essential to local waste management campaigns in his field site in Tacna, Peru. The same may be said of Accra. Though the historical archives and geographic surveys say otherwise, the prevailing view of waste along the lagoon-and that advanced by the media and city officials-is that it is largely (or even entirely) the fault of the slum. Consequently, when discussing solutions, many propose the removal of
Old Fadama, which they view as the main cause of refuse pileups near the Korle. As I argue elsewhere, this particular perception of trash forms an essential part of the city's policy of "decongestion". In constructing waste and the slum as detrimental to the lagoon, officials are then able to mobilize popular support for urban renewal programmes to remove the pollution-i.e. both the waste and those who handle it-from the city. Thus such perceptions of waste contribute to an exclusionary geography, which justifies the excision of its poorest residents from the city center (Onuoha, 2014). Alternative views of the role of refuse and its recyclers along the lagoon, might correspondingly allow for the conception of other approaches to waste management in the city, besides the displacement of 100,000 people from the urban landscape.

Therefore instead of focusing solely on how inputs and outputs enter and leave the city, this paper has examined, as was suggested by Gandy in his "Rethinking Urban Metabolism," the social dimensions of trash along the Korle Lagoon. In the absence of adequate infrastructure and urban policies, residents of Old Fadama have created various recycling networks that channel some of Accra's waste into more economically productive means. Thus, this paper has argued that rather than exacerbating the problem, residents may be said to have helped mitigate it. For new migrants to the city, moving to the Old Fadama slum provides them with a preliminary residence. Additionally, those who have lived in the slum for some time argue that in the absence of adequate job and home creation by the AMA, the Korle helps them to make a decent living rather than resorting to a life of crime. Lastly, my examination of the different social impacts of the lagoon shows how working in recycling helps to create various social hierarchies within the settlement. 


\section{References}

Acquah, Ioné. 1958. "Accra Survey : a Social Survey of the Capital of Ghana, Formerly Called the Gold Coast, Undertaken for the West African Institute of Social and Economic

Research, 1953-1956". London: University of London Press.

Apt, Nana Araba. 2002. "Accra in 21st Century: Visions from the Crystal Ball of a Sociologist." In Visions of the City: Accra in the 21st Century, edited by Ralph Mills-Tettey and Korantema Adi-Darko, 39-48. Accra: Woeli Publishing Services.

The Black Narrator. 2013. "Garbage Nightmare." Accra.

Accessed Dec 4, 2014. https://www.facebook.com/bnarrator/photo /a.182562595248421.1073741828.165283213643026/283074381863908/

Blacksmith Institute and Green Cross Switzerland. 2013. “The World's Worst 2013: The Top Ten Toxic Threats - Cleanup, Progress, and Ongoing Challenges." In The World's Worst. 1-36. Accessed Dec 4, 2014. http://www.worstpolluted.org/docs/ TopTenThreats2013.pdf

Boadi, Kwesi Owusu and Kuitunen Markku. 2002. "Urban Waste Pollution in the Korle Lagoon, Accra, Ghana." Environmentalist 22(4): 301-309.

Boadi, Kwesi Owusu and Kuitunen Markku. 2003. "Municipal Solid Waste Management in the Accra Metropolitan Area, Ghana.” Environmentalist 23(3): 211-218.

Cronon, William. 1996. "The Trouble with Wilderness; or Getting Back to the Wrong Nature." In Uncommon Ground: Rethinking the Human Place in Nature, 69-90. New York: W.W. Norton \& Company.

The Daily Graphic. 2012. “The Dead Odaw River - Polluted With Plastics, Garbage \& Human Excreta." GhanaWeb. Mar 13 2012. http://www.ghanaweb.com/GhanaHomePage/ NewsArchive/The-Dead-Odaw-River-Polluted-With-Plastics-Garbage-Human-Ex creta- 232440

Drackner, Mikael. 2005. "What is waste? To whom? - An anthropological perspective on garbage." Waste Management \& Research 23 (3): 175-181.

Environmental Protection Agency. 2000. Environmental Impact Assessment-Dredging of Korle Lagoon. Accra: Ministry of Works and Housing and Accra Metropolitan Assembly.

Gandy, Matthew. 2010. "Rethinking Urban Metabolism: Water, Space and the Modern City." City: Analysis of Urban Trends, Culture, Theory, Policy, Action 8(3): 363-379.

Ghana Statistical Service (GSS). 2008. Ghana Living Standards Survey. GLSS: 5. Accra.

Girardet, Herbet. 2010. "Regenerative Cities." Report presented to the World Future Council and HafenCity University's Commission on Cities and Climate Change. Hamburg. Accessed Dec 4, 2014. http://www.worldfuturecouncil.org/fileadmin/user_upload/ papers/WFC_Regenerative_Cities_web_final.pdf 
International Marine and Dredging Consultants (IMDC). 2000. Physico-Chemical and Bio logical Study (General EIA Study) for KLERP. New York and Brussels: Ministry of Works and Housing.

Kuria, Florence. 2009. Ghana: Urban Profile. Nairobi: United Nations Human Settlements Programme (UN-HABITAT).

Moates, A Shiloh. 2010. "Clasificadores: "Living Off the Trash" and Raising Hogs at the Urban Margin.” Culture \& Agriculture 32(2): 50-60.

Onuoha. 2014. "Decongesting Accra." Johannesburg Salon. 7(1): 123-130. http://jwtc.org.za/ resources/docs/salon-volume-7/TheSalon_Vol7.pdf

---. 2014. Fadama. Documentary film. 25 minutes.

---. Forthcoming. “The Lesser Evil: Dumping as environmental choice in Accra, Ghana". West African Research Association.

Parizeau, Kate. 2015. "Re-representing the city: waste and public space in Buenos Aires, Argentina in the late 2000s." Environment and Planning A 47(2): 284-299.

Patterson, K. David. "Health in Urban Ghana: The Case of Accra 1900-1940." Social Science \& Medicine. Part B: Medical Anthropology 13, no. 4 (December 1979): 251-68.

Public Records and Archives Administration Ghana (PRAAD). 1. "CSO/14/1/389 - Korle Lagoon Outfall Gate" (Letter from Financial Secretary ES Packman to the Director of Public Works, February 12, 1947)

--PRAAD. 2 "RG/7/1/165/13 - Memorandum on the Sewerage of Accra." Jan 6, 1956. --PRAAD. 3 "RG/7/1/165/82 - Funds for Sewerage and Surface Water Drainage Scheme for Accra” (J.A Addo (Town Clerk) to Permanent Secretary, April 5, 1957) and "RG/7/1/165 - Letters from the JS Duthie, Secretary from Development in Reply to the 'Memorandum on the Sewerage of Accra," March 26, 1956.

--PRAAD. 4 Public Records and Archives Administration (Ghana), "RG.5/1/194/1518 - Official Opening of Guggisberg Bridge." Sept 16, 1963. 
Radio XYZ Online. 2013. "Sodom and Gomorrah to be Cleared for $\$ 600 \mathrm{~m}$ Project Mayor." GhanaWeb. January 17. Accessed Dec 10, 2013. http://www.ghanaweb.com/ GhanaHomePage/NewsArchive/Sodom-and-Gomorrah-to-be-cleared-for-600mproject-Mayor-262419

Roberts, Jonathan. "Korle and the Mosquito: Histories and Memories of the Anti-Malaria Campaign in Accra, 1942-5." The Journal of African History 51, no. 03 (November 2010): 343-65.

Tahal Water Planning Ltd. 1965. Master Plan for Water Supply and Sewerage - Government of Ghana. Arcadia: Engineering Sciences, Inc.

The Weekend Globe. 2013. "Accra is Sitting on a Waste Timebomb." GhanaWeb. July 7. Accessed Dec 4, 2014. http://www.ghanaweb.com/GhanaHomePage/NewsArchive/ Accra-is-sitting-on-a-waste-time-bomb-278867

Whitson, Risa. 2011. "Negotiating Place and Value: Geographies of Waste and Scavenging in Buenos Aires." Antipode 43 (4): 1404-1433.

Wolman, Abel. 1965. “The Metabolism of Cities.” Scientific American 213(3): 179-190.

Youtube. 2011. "Sodom and Gomorrah...Between a City and its Dream". Selasekove. Dec 14. Accessed Dec 10, 2013. https://www.youtube.com/watch?v=fVjCN4Y14Zs 